\title{
Scholars and Literati at the Royal Spanish Academy (1713-1800)
}

\author{
David de la Croix \\ IRES/LIDAM, UCLouvain
}

\author{
Julie Duchêne \\ ILEE, UNamur
}

This note is a summary description of the set of scholars and literati who were members of the Royal Spanish Academy (Real Academia Española) from its creation in 1713 to the eve of the Industrial Revolution (1800).

\section{The ACADEMY}

The Spanish Royal Academy (Real Academia Española in Spanish) was founded in 1713 in Madrid by the Marquis of Villena and Duke of Escalona, Juan Manuel Fernández Pacheco y Zúñiga. It was inspired by the Academia della Crusca, founded in 1583 in Italy, and the Académie Française, founded in 1635. In 1714, the Academy was officially recognised by the King of Spain, Philip V, who approved its constitution by royal decree. Like its two models, the Royal Spanish Academy is entirely dedicated to language. With this institution, the objective of its founder and first director is to "fix the sounds and words of the Castilian language in their greatest property, elegance and purity." This mission continues to guide the activity of the Academy, which is responsible for ensuring "the preservation of the proper use and unity of a language that is constantly evolving and expanding".

\section{SOURCES}

On its website, the Spanish Royal Academy provides an exhaustive list of its members since its creation (Real Academia Española 2021). Each entry contains a biography and bibliographical references.

\section{SOME STATISTICS}

Table 1 shows some descriptive statistics. There are 117 scholars and literati. The year of birth is known for $82.9 \%$ of them. The mean age at nomination is 39.3 years, decreasing over time. This reflects the fact that the Academy started with relatively old and established scholars, who were replaced over time by younger ones. Longevity (mean age at death \& expected age at death when 30) slightly increases over time. The birthplace is known for $85.5 \%$ of the individuals. The median distance between birthplace and Madrid, the seat of the Academy, is $282 \mathrm{~km}$ over the whole period, reflecting that the scholars were native from all over Spain. This mean distance is quite stable over time. Finally, $47.9 \%$ of the scholars have a Wikipedia page (in some language), and $66.7 \%$ of them have left a footprint in the catalogues of the libraries of the world, Worldcat, either by having published some work, or by having been the subject of published books and articles.

\section{FIELDS}

Figure 1 shows the relative importance of fields. Due to the literary orientation of the Spanish Royal Academy, the main fields are literature and, more broadly, the humanities. 


\begin{tabular}{ccccccc}
\hline \multicolumn{2}{c}{ Period } & nb. & \% birth year & mean age & $\begin{array}{c}\text { mean age } \\
\text { at death }\end{array}$ & $\begin{array}{c}\text { exp. age } \\
\text { at death }\end{array}$ \\
\hline 1686 & 1733 & 47 & 87.2 & 43.6 & 64.3 & 60.2 \\
1734 & 1800 & 70 & 80 & 36.2 & 64.4 & 62.6 \\
\hline 1000 & 1800 & 117 & 82.9 & 39.3 & 64.4 & 62.2 \\
\hline \multicolumn{8}{c}{ \% birthplace } & median distance & \% with & $\%$ with \\
\hline 1686 & 1733 & known & birth-institution & Wikipedia & Worldcat \\
\hline 1734 & 1800 & 85.1 & 255 & 40.4 & 55.3 \\
\hline 1000 & 1800 & 85.7 & 305 & 52.9 & 74.3 \\
\hline
\end{tabular}

Table 1: Summary statistics by period

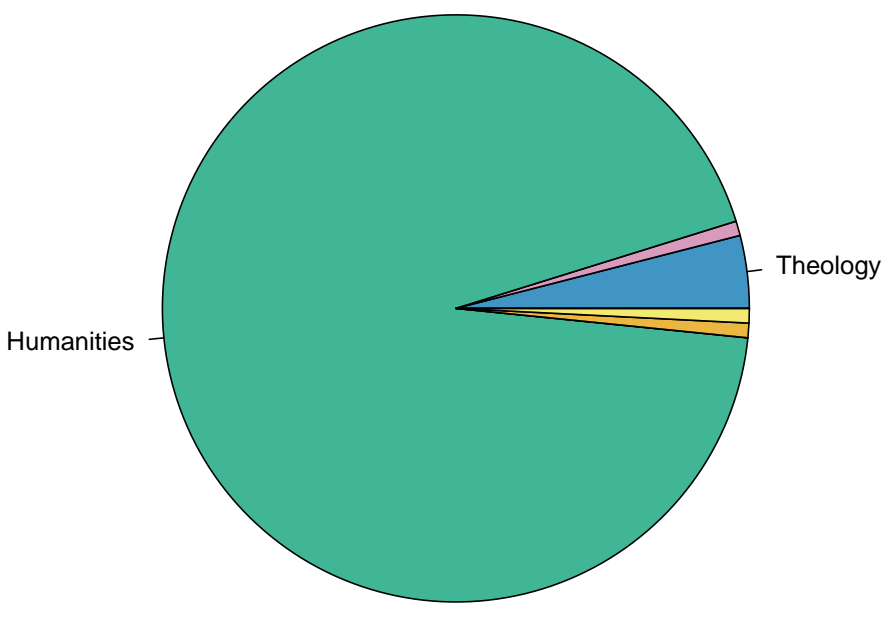

Figure 1: Broad fields at Madrid 


\section{Place OF BIRTH}

Figure 2 is a plot of the places of birth of all the scholars of the Royal Spanish Society, and shows, not surprisingly, the Spanish character of this academy.

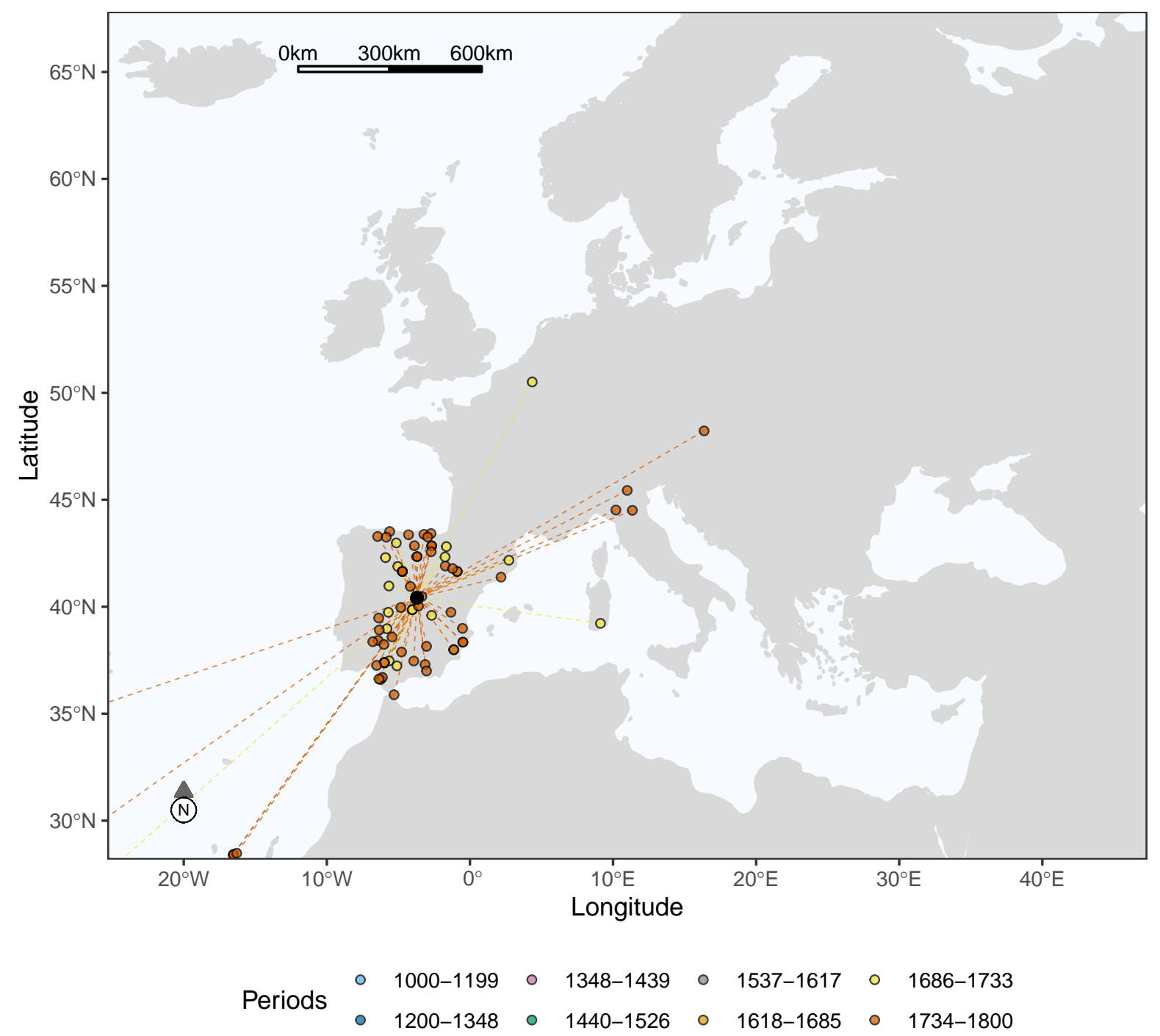

Figure 2: Place of birth of the scholars and literati at the Royal Spanish Academy

\section{HUMAN CAPITAL OF SCHOLARS AND LITERATI}

For each person in the database we compute a heuristic human capital index, identified by combining information from Worldcat and Wikipedia using a principal component analysis. Details are given in the Appendix. Figure 3 shows the names of all the scholars with a positive human capital index. The vertical green lines (rug plot) show the distribution of all scholars, including the obscure ones, over time.

\section{TOP 5 SCHOLARS}

The academy has many published scholars, signalling both productivity and prominence. A brief overview of the five scholars with the highest human capital index follows. 


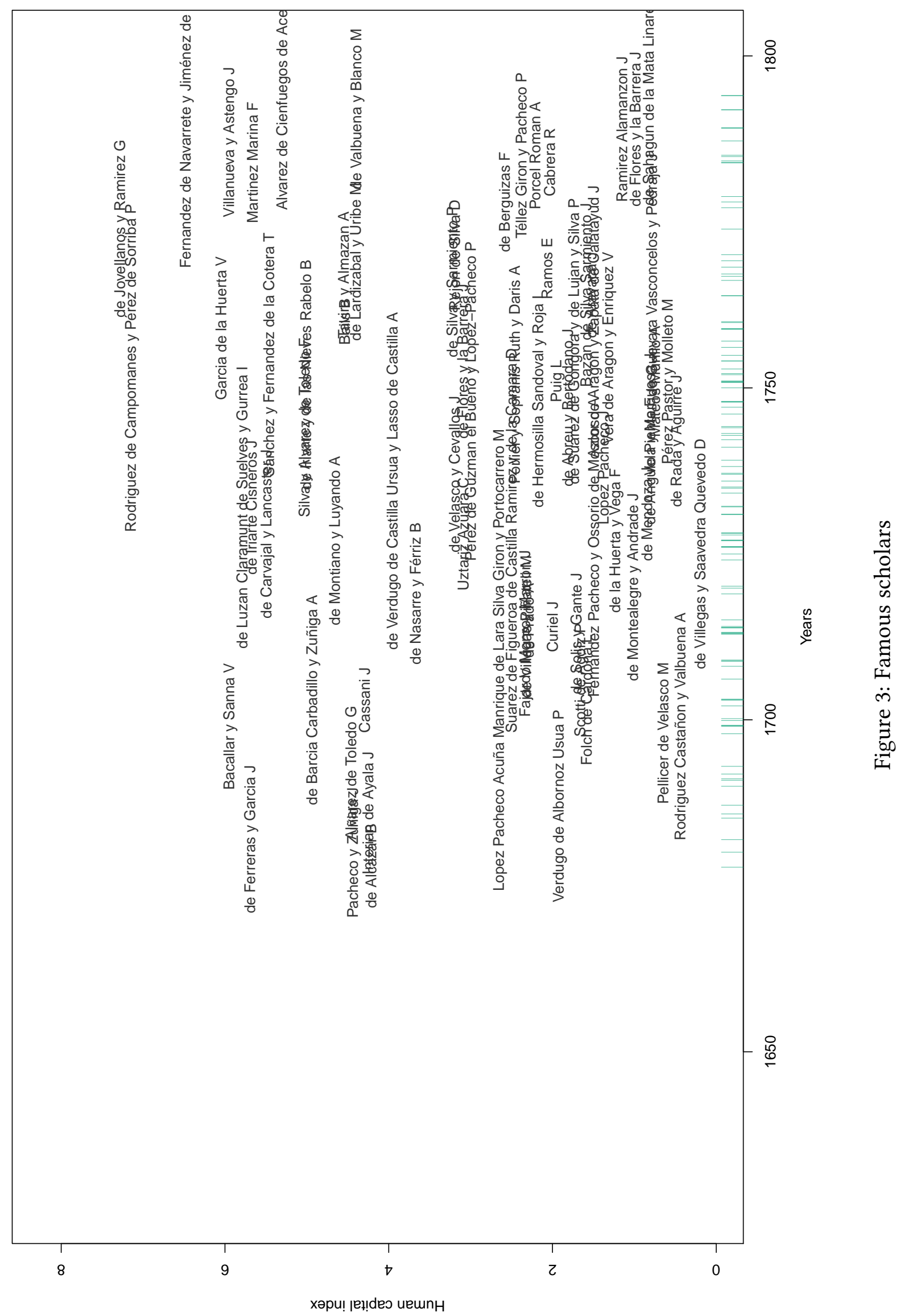


Gaspar Melchor de Jovellanos y Ramirez (Gijón 1744 - Puerto de Vega 1811) was among the important personalities of the 18th century. A lawyer, jurist, economist, politician and famous writer, he had many areas of expertise. Among his works, he is renowned for the elaboration of a vast bibliography mainly comprising essays on social, economic or political subjects. In 1783, he was elected to the V seat of the Academy, a position he held until his death in 1811, although the political unrest at the end of the 18th century prevented him from taking up his seat as an academician on several occasions.

Pedro Rodriguez de Campomanes y Pérez de Sorriba (Sorriba 1723 - Madrid 1802) was a politician and a lawyer. During his professional career, he held several important positions, including that of lawyer to the Royal Councils of Vastilla in 1745 and President of the Council of Castile in 1783. As an intellectual, he was a member of several cultural and scientific institutions in Spain and abroad. He was a member of the Royal Spanish Academy from 1763 and director of the Royal Academy of History for more than thirty years. In 1791 he retired from public life and resigned from all his academic posts and chairs.

Martin Fernandez de Navarrete y Jiménez de Tejada (Abalos 1765 -- Madrid 1844) obtained a seat at the Spanish Royal Academy in 1797, although he had been an honorary member since 1792. Trained during his youth in different disciplines, from Latin grammar to physics, he was a figure of the Enlightenment movement in Spain. He distinguished himself as a historian, but also in the Navy, which he joined in 1780 after completing his studies. Apart from the Spanish Royal Academy, he was a member of several cultural institutions, such as the Royal Academy of History, of which he was director from 1823 until his death in 1844. His investment in the different academies of which he was a member made Fernández de Navarrete a reference point in Spanish culture.

Vicente Antonio Garcia de la Huerta (Zafra 1734 - Madrid 1787) was a famous Spanish writer. He was one of the main personalities of the 18th century Spanish literary world. His first work is a heroic poem, entitled Endimión and dedicated to the Duke of Huéscar, which he published in 1755 at the age of 21. Among his patrons was the Duke of Alba Fernando de Silva Álvarez de Toledo, director of the Spanish Royal Academy from 1754 to 1776. García de la Huerta was not shy about attracting criticism, as he did with the sixteen volumes of his work Spanish Theatre, in which he attacked French classicism. However, he also received numerous distinctions and was elected to several academic institutions. He joined the Royal Spanish Academy in 1760.

Joaquin Lorenzo Villanueva y Astengo (Játiva 1757 - Dublin 1837) followed during his career the path of his family, traditionally oriented towards literature and politics and linked to the clergy. A former student of the University of Valencia, Villanueva is known as a religious scholar, politician and writer. His liberal approach, expressed in his writing, attracted several controversies which eventually lead to his exile in Great Britain. His favourite subjects were religious and political. Elected in 1796 to the Spanish Royal Academy, he had little opportunity to attend because of the upheavals surrounding his publications. However, the Academy continued to pay him a pension throughout his exile, which lasted until his death in Dublin in 1837.

\section{RELATED SCHOLARS}

Two other important individuals were related to the Academy. Whether they occupied an official position is not clear. Those scholars are counted in all figures, except Figure 3.

Clotilde Tambroni (Bologna 1758 - Bologna 1817) was an Italian linguist and poetess. She is particularly well known as a scholar of Greek. Her skills earned her the chair of Ancient Greek at the University of Bologna in 1793 and thus she became the first university teacher to have not studied and obtained a degree. She learned Greek from the Spanish Jesuit Emanuele 
Rodriguez Aponte who rented a room at her parents' house. According to tradition, she used to listen to the lessons he gave to his private students. One day, she revealed her knowledge by answering in the place of the student of the day. According to Istituto dell'Enciclopedia Italiana (1961), Clotilde Tambroni joined the Royal Spanish Academy in 1798, when she relocated to Spain after Napoleon Bonaparte invaded Italy. She returned to Italy two years later, where she regained her professorship and occupied it until 1808, the year in which the teaching of Greek was abolished by a Napoleonic reform to give priority to scientific studies.

Betti Zaccaria (Verona 1732 -- Verona 1788) was an Italian agronomist and poet. He was an active participant in the European agricultural revival movement of the 18th century, particularly through his advice on how to destroy the harmful insects on the leaves of apple trees. His recommendations remained authoritative for several years and were integrated into farmers' practices. His contributions as an agronomist and his literary output led him to join several academies in Italy and abroad, such as the Agricultural Academy of Verona and, according to the Italian Encyclopedia Istituto dell'Enciclopedia Italiana (1961), the Spanish Royal Academy in 1775 .

\section{DiVERSITY}

A special feature of the Royal Spanish Academy is that in 1784 it probably welcomed the first female academician in Spain, María Isidra Quintina de Guzmán, although she did not return to the Academy after her speech of thanks (Lewis, Peruga, and Jaffe 2019). María Isidra was also the first woman to obtain the title of Doctor in Spain (Ayres-Bennett and Sanson 2020). The Academy did not have any more women in its ranks until 1978, when Carmen Conde was appointed.

\section{INTERSECTIONS WITH NEARBY UNIVERSITIES}

Among the 117 academicians, 111 do not appear on university rolls at the University of Salamanca, the most well-known Spanish university at that time. Figure 4 shows this intersection. The two worlds, university and academy, are thus not totally distinct, but the intersection is small.

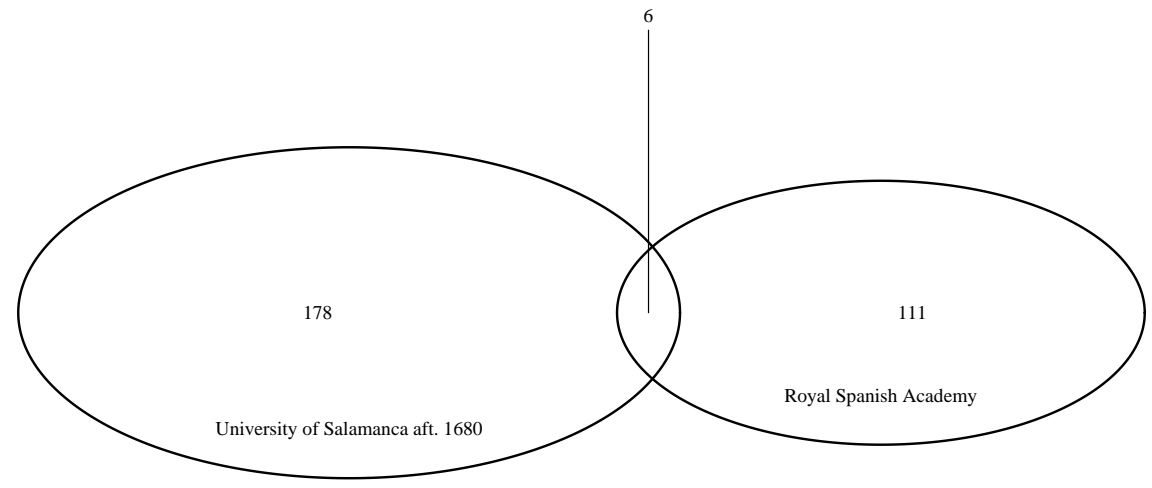

Figure 4: Intersections of the lists of scholars between the University of Salamanca and the Royal Spanish Academy

\section{AneCDOTES}

In a recent work of fiction, Hombres Buenos (Good Men), Pérez-Reverte (2015) pays homage to the Royal Spanish Academy, of which he has been a member since 2003. In the 18th century the two good men of the title, librarian and philologist Hermogenes Molina and Admiral Pedro Zarate, 
author of a marine dictionary, were sent by the Academy to Paris to bring back a complete copy of D'Alembert and Diderot's Encyclopedia, which was banned in Spain at the time. This brought them into conflict with a movement in Spain, lead by the Church, that opposed the Enlightenment and sought to undermine their quest.

\section{ApPENDIX}

The individual human capital index $q_{i}$ of an individual $i$ is given by:

$$
\begin{aligned}
q_{i}= & -1.76+0.43 \ln (\mathrm{nb} . \text { characters of the longest Wikipedia page }) \\
& +0.40 \ln (\mathrm{nb} . \text { Wikipedia pages in different languages })+0.47 \ln (\text { nb. works in Worldcat }) \\
& +0.46 \ln (\mathrm{nb} . \text { publication languages in Worldcat })+0.47 \ln (\mathrm{nb} \text {. library holdings in Worldcat })
\end{aligned}
$$

We assume that having no Wikipedia page is similar to having one page with a length of 60 characters and that having no Worldcat page is similar to having a page with one work in one language held by one library. The constant -1.76 normalizes $q_{i}$ at 0 when there is neither a Wikipedia page, nor a Worldcat page. The weights $(0.43,0.40$, etc) are obtained from the first principal component of the five indicators (De la Croix et al. 2020).

\section{ACKNOWLEDGMENTS}

This project has received funding from the European Research Council (ERC) under the European Union's Horizon 2020 research and innovation programme, under grant agreement No 883033 "Did elite human capital trigger the rise of the West? Insights from a new database of European scholars."

First version March 5, 2021, updated November 3, 2021.

\section{REFERENCES}

Ayres-Bennett, Wendy, and Helena Sanson. 2020. Women in the History of Linguistics. Oxford University Press.

De la Croix, David, Frédéric Docquier, Alice Fabre, and Robert Stelter. 2020. "The Academic Market and the Rise of Universities in Medieval and Early Modern Europe (1000-1800)." CEPR Discussion Paper 14509.

Istituto dell'Enciclopedia Italiana. 1961. Treccani. Dizionario Biografico degli italiani. Roma: Istituto dell'Enciclopedia Italiana. Also available at https://www.treccani.it/.

Lewis, Elizabeth Franklin, Mónica Bolufer Peruga, and Catherine M Jaffe. 2019. The Routledge Companion to the Hispanic Enlightenment. Routledge.

Pérez-Reverte, Arturo. 2015. Hombres buenos. Alfaguara.

Real Academia Española. 2021. "Historia de la Real Academia Española." https://www.rae.es/ la-institucion/historia. 